\title{
ASSESSMENT ON FACTORS AFFECTING ADOPTION AND TOTAL INCOME FROM VERMICOMPOST PRODUCTION IN CHITWAN, NEPAL
}

\author{
D. Devkota ${ }^{1}$, S. C. Dhakal' ${ }^{2}$ D. Dhakal ${ }^{3}$, D. D. Dhakal ${ }^{3}$, R. B. Ojha ${ }^{4}$ \\ ${ }^{1}$ Nepal Agricultural Research Council, Kathmandu, Nepal, ${ }^{2}$ Agriculture and Forestry University, \\ Chitwan, Nepal, ${ }^{3}$ Institute of Agriculture and Animal Sciences, Tribhuvan University ${ }^{4}$ Himalayan \\ College of Agriculture Science and Technology, Purwanchal University, Nepal.
}

\begin{abstract}
Vermicompost production technology uses half decomposed organic wastes to feed earthworms which produces nutrient enriched compost. Vermicompost production supports both organic waste management as well as organic farming. A research was conducted with the aim to assess the production and marketing aspect of vermicompost in Chitwan district during the year 2013. Interview schedule was used to collect information from all the 32 vermicompost producers within the study area and 32 adjacent non-producers were selected through snowball sampling. The total respondents' size was 64 . The non-producers were farmers with few of them vermicompost users. Training on vermicompost production, group membership and type of farming were the significant factors affecting adoption of vermicompost production technology whereas the volume of earthworm reared and labor use were the significant factors affecting total income from vermicompost production. Resource use efficiency revealed that volume of earthworm reared and material cost were being over utilized but the labor use was underutilized. The volume of earthworm reared and labor use was to be increased by $300 \%$ and $1.48 \%$ respectively to obtain optimum economic advantage.
\end{abstract}

Keywords: Earthworms, Training, Membership, Resource use efficiency

\section{INTRODUCTION}

Economic prosperity in Nepal is directly related to the sustainable development of the agricultural sector as it contributes one-third of the total GDP (MoAD, 2013) and employs 65.6\% of total population (Agriculture Diary, 2013). Now-a-days farmers are using more chemical fertilizers and less farm yard manures in order to fulfill the increasing demand for food. Production may increase in the short run with the use of chemical fertilizers but in the long run it reduces production, destroys soil properties and causes environmental pollution along with many other detrimental effects. This has led to decreased agricultural production and productivity. Thus to enhance soil fertility and make sustainable agriculture production, organic farming is very important. Employing organic farming methods lead to higher profits for farmers not only because of price premiums, but also because of lower production costs (Rosegrant and Ringler, 2005).

According to Practical Action Nepal (2008) organic wastes account for $50 \%$ to $70 \%$ of total solid wastes which can be managed through vermicomposting to produce organic manure. Earthworms ingest half of decomposed organic wastes and produce excreta known as vermicompost which is organic and beneficial for improving soil health. Vermicomposting is an effective method 
of converting "garbage to gold" (Vermi Co, 2001; Tara Crescent, 2003). Vermicompost is one of the best alternatives among organic manures as a soil amendment input. This involves easy rearing procedures and low initial investment but high price of the final product. The major input to this production technology is organic waste. Input itself being waste, this technology does not involve high initial investment. This technology has the potential to engage small farmers and women who can easily set up such units at the household level and no specific skill is required. Raising the number of vermicompost producers and productivity of existing producers is very crucial for sustainable agriculture production.

Thus, the study was carried out to attain following objectives:

- To assess factors affecting adoption of vermicompost production technology.

- To determine factors affecting total income from vermicompost production technology.

- To assess resource use efficiency in vermicompost production.

\section{METHODOLOGY}

The highly potential Chitwan district of Narayani zone which lies in the mid-southern area of Nepal was purposively selected for the study as there are remarkable numbers of small scale vermicompost producers in this district. Census survey was conducted which included all the vermicompost producers within the district. Altogether, there were 32 vermicompost producers within the district at the time of survey. The list of vermicompost producers within the district was obtained from DADO, Chitwan and other related organizations. Similarly 32 adjacent non producers were selected by snow ball sampling ${ }^{1}$. Thus, the total respondent size was 64 . Interview schedule was prepared for collecting primary information from both vermicompost producers and adjacent non producers.

Probit model was used to study factors affecting adoption of vermicompost production technology. Probit is used to estimate binary variable regression models (Gujarati, 1978). The marginal effect on the probability of adoption was also calculated. Mathematically the model was expressed as:

$$
\mathrm{Yi}=\alpha+\beta_{1} \mathrm{X}_{1}+\beta_{2} \mathrm{X}_{2}+\beta_{3} \mathrm{X}_{3}+\beta_{4} \mathrm{X}_{4}+\beta_{5} \mathrm{X}_{5}+\beta_{6} \mathrm{X}_{6}+\beta_{7} \mathrm{X}_{7}
$$

Where,

$\mathrm{Yi}=$ Factors affecting adoption of vermicompost production technology

$\alpha=$ Regression coefficient

$\beta_{1} \ldots \ldots \ldots \ldots \ldots . . . . . . \beta_{7}=$ Probit coefficients

\footnotetext{
${ }^{1}$ Snow ball sampling is non probability sampling technique in which a respondent gives information about other respondents in his or her contact.
} 
Table 1. Description of the variables used in the probit model.

\begin{tabular}{|c|c|c|c|c|}
\hline Variables & Type & Description & Value & Expected sign \\
\hline $\begin{array}{l}\text { Dependent } \\
\text { variable } \\
\text { Yi }\end{array}$ & Dummy & $\begin{array}{l}\text { Factors affecting adoption } \\
\text { of vermicompost production } \\
\text { technology }\end{array}$ & $\begin{array}{l}1 \text { if adopter; } \\
0 \text { otherwise }\end{array}$ & \\
\hline $\begin{array}{l}\text { Independent } \\
\text { variables }\end{array}$ & & & & \\
\hline $\operatorname{Age}\left(X_{1}\right)$ & Continuous & Age of the household head & years & $+/-$ \\
\hline $\operatorname{Gender}\left(\mathrm{X}_{2}\right)$ & Dummy & Gender of the household head & $\begin{array}{l}1 \text { if female; } \\
0 \text { otherwise }\end{array}$ & $+/-$ \\
\hline Education $\left(\mathrm{X}_{3}\right)$ & Continuous & $\begin{array}{l}\text { Years of schooling of the } \\
\text { household head }\end{array}$ & years & + \\
\hline $\begin{array}{l}\text { Economically } \\
\text { active } \\
\text { members }\left(\mathrm{X}_{4}\right)\end{array}$ & Continuous & $\begin{array}{l}\text { Number of economically } \\
\text { active (15-59years) family } \\
\text { members in the household }\end{array}$ & Number & + \\
\hline Training $\left(\mathrm{X}_{5}\right)$ & Dummy & $\begin{array}{l}\text { Whether the respondents } \\
\text { received training on } \\
\text { vermicompost production }\end{array}$ & $\begin{array}{l}1 \text { if received } \\
\text { training; } 0 \\
\text { otherwise }\end{array}$ & + \\
\hline $\begin{array}{l}\text { Membership } \\
\left(\mathrm{X}_{6}\right)\end{array}$ & Dummy & $\begin{array}{l}\text { Membership of the } \\
\text { respondents in group }\end{array}$ & $\begin{array}{l}1 \text { if yes; } 0 \\
\text { otherwise }\end{array}$ & + \\
\hline Farming $\left(\mathrm{X}_{7}\right)$ & Dummy & $\begin{array}{l}\text { Type of farming practiced by } \\
\text { the respondents }\end{array}$ & $\begin{array}{l}1 \text { if organic; } \\
0 \text { otherwise }\end{array}$ & + \\
\hline
\end{tabular}

Cobb-Douglas production function is widely used in agricultural researches because of its simplicity for the comparison of coefficients of partial elasticity (Prajneshu, 2008). Cobb-Douglas production function was used to determine the contribution of different explanatory variables on total income from vermicompost and earthworm production. The production function was expressed as: $\mathrm{Y}=\mathrm{aX}_{1}^{\mathrm{b} 1} \mathrm{X}_{2}^{\mathrm{b} 2} \mathrm{X}_{3}^{\mathrm{b} 3} \mathrm{e}^{\mathrm{u}}$

Where,

$\mathrm{Y}=$ Total income from vermicompost and earthworm (NRs.)

$\mathrm{X}_{1}=$ Value of earthworm reared (NRs.)

$\mathrm{X}_{2}=$ Total labor cost (NRs.)

$\mathrm{X}_{3}=$ Total variable material cost (NRs.)

$\mathrm{u}=$ Random disturbance term and $\mathrm{b}_{1} \ldots \mathrm{b}_{3}$ are the coefficients to be estimated.

The Cobb- Douglas production function expressed above was made linear to a logarithmic function in order to organize it for practical purposes as expressed below:

$\ln \mathrm{Y}=\ln \mathrm{a}+\mathrm{b}_{1} \ln \mathrm{X}_{1}+\mathrm{b}_{2} \ln \mathrm{X}_{2}+\mathrm{b}_{3} \ln \mathrm{X}_{3}+\mathrm{u}$

Where,

$\ln =$ Natural logarithm, $\mathrm{a}=$ constant and $\mathrm{u}=$ Error term 
Table 2. Description of the variables used in the Cobb-Douglas production function analysis.

\begin{tabular}{lll}
\hline Variables & Unit & Description \\
\hline $\begin{array}{l}\text { Income from vermicompost } \\
\text { and earthworm }\end{array}$ & NRs. & $\begin{array}{l}\text { It indicates the total income from the production of } \\
\text { vermicompost and earthworm. } \\
\text { It refers to the total value of earthworms being reared } \\
\text { considering NRs. 1 per earthworm which was the } \\
\text { average market price per earthworm. }\end{array}$ \\
$\begin{array}{lll}\text { Labor cost } \\
\text { Material cost }\end{array}$ & NRs. & $\begin{array}{l}\text { It includes total labor cost for vermicompost and } \\
\text { earthworm production. }\end{array}$ \\
\hline
\end{tabular}

The Cobb-Douglas production function was also used to calculate return to scale from vermicompost and earthworm production using the following formula:

Where,

$$
\text { Return to scale }(\mathrm{RTS})=\sum \mathrm{b}_{\mathrm{i}}
$$

$\mathrm{b}_{\mathrm{i}}=$ Coefficient of $\mathrm{i}^{\text {th }}$ variables

Resource use efficiency for vermicompost production was determined by the ratio of Marginal Value Product (MVP) to Marginal Factor Cost (MFC) of variable inputs based on the estimated regression coefficients. With reference to Rahman and Lawal (2003) efficiency of resource use was calculated using the following formula:

$\mathrm{r}=\mathrm{MVP} / \mathrm{MFC}$

Where,

$\mathrm{r}=$ Efficiency ratio

$\mathrm{MVP}=$ Marginal value product of a variable input

$\mathrm{MFC}=$ Marginal factor cost (Price per unit input)

The decision rule for the efficiency analysis was as follows:

$\mathrm{r}=1$; Efficient use of a resource

$\mathrm{r}>1$; Underutilization of a resource

$\mathrm{r}<1$; Overutilization of a resource

Furthermore, to obtain optimal resource allocation i.e. $r=1$ or MVP $=$ MFC the relative percentage change in MVP of each resource was estimated using the following equation:

$\mathrm{D}=(1-\mathrm{MFC} / \mathrm{MVP}) \times 100$

Or, $\mathrm{D}=(1-1 / \mathrm{r}) \times 100$

Where,

$\mathrm{D}=$ Absolute value of percentage change in MVP of each resource

$\mathrm{r}=$ efficiency ratio

\section{RESULTS AND DISCUSSION}

Factors affecting adoption of vermicompost production technology

Probit model was used to assess the factors affecting adoption of vermicompost production technology. Marginal effects were also calculated from the regression coefficients. The output is presented in Table 3. Dependant variable was the adoption of the respondents in the study area 
which was categorized into binary response as 1 if adopter and 0 otherwise. The Wald test (LR chi $)$ for the model indicates that the model has good explanatory power at $1 \%$ level. The Pseudo $\mathrm{R}^{2}$ is 0.56. The Hosmer-Lemeshow' goodness-of-fit yielded a Chi-square with a large P-value indicating that the model fits the data well. Overall, the model predicted $35.84 \%$ of the samples correctly. Probit regression analysis showed that three variables were statistically significant factors affecting adoption. They were training, group membership and type of farming. Other variables such as age, gender, education and economically active members appeared to be statistically non-significant with age and education being positively associated while gender and economically active members were being negatively associated with the adoption.

Table 3. Factors affecting adoption of vermicompost production technology in the study area.

\begin{tabular}{|c|c|c|c|c|c|}
\hline Variables & Coefficients & Std. error & $\mathrm{P}>|\mathrm{z}|$ & $\mathrm{dy} / \mathrm{dx}^{\mathrm{b}}$ & S.E $E^{b}$ \\
\hline Age & .002 & .036 & 0.959 & .001 & .014 \\
\hline Gender & -.374 & .621 & 0.547 & -.148 & .242 \\
\hline Education & .069 & .055 & 0.211 & .028 & .022 \\
\hline Economically active members & -.061 & .199 & 0.759 & -.024 & .079 \\
\hline Training & $2.485 * *$ & .863 & 0.004 & .768 & .143 \\
\hline Membership & $1.641 *$ & .731 & 0.025 & .554 & .161 \\
\hline Farming & $1.134 *$ & .548 & 0.039 & .427 & .183 \\
\hline Constant & -3.113 & 2.145 & 0.147 & - & - \\
\hline \multicolumn{6}{|l|}{ Summary statistics } \\
\hline Number of observation $(\mathrm{N})$ & \multicolumn{5}{|c|}{64} \\
\hline Log likelihood & \multicolumn{5}{|c|}{-19.53} \\
\hline $\operatorname{LR} \operatorname{chi}^{2}(7)$ & \multicolumn{5}{|c|}{$49.66 * *$} \\
\hline Prob $>$ chi $^{2}$ & \multicolumn{5}{|c|}{0.00} \\
\hline Pseudo $\mathrm{R}^{2}$ & \multicolumn{5}{|c|}{0.56} \\
\hline Cases predicted correctly $(\%)$ & \multicolumn{5}{|c|}{35.84} \\
\hline Goodness of fit test & \multicolumn{5}{|c|}{ Pearson $\operatorname{chi}^{2}(56)=37.35$. Prob $>$ chi $^{2}=0.97$} \\
\hline
\end{tabular}

Source: Field Survey, 2013

** Significant at $1 \%$ level of significance; * Significant at $5 \%$ level of significance.

${ }^{b}$ Marginal change in probability (marginal effects after Probit) evaluated at the sample means

The analysis revealed that coefficient of training was positive and highly significant. It means that if respondents had received training related to vermicompost production then the probability of adoption would increase by $76.8 \%$.

Membership was also positively significant and indicates if respondents had membership of group then the probability of adoption would increase by $55.4 \%$. Likewise, farming was also positively significant and it was found that if the respondents had practiced organic farming then the probability of adoption would increase by $42.7 \%$.

The results revealed that training was the most significant factor affecting adoption of vermicompost production technology followed by group membership and type of farming. The study carried out by ICIMOD (2011) in Rasuwa, Godavari, Nuwakot and Bishankhunarayan VDCs revealed that more than $60 \%$ of the farmers who received training adopted vermicomposting production technology and started selling earthworms to fellow farmers. 
Likewise, in the study conducted during the year 2011in Belgaum district of Karnataka to access the impact of training on vermicompost production technology it was found that hundred percent trainees fully adopted recommended practices of vermicomposting. But age, occupation, land holding, annual income and risk orientation appeared to be non-significant (Hiremath, 2013).

\section{Factors affecting total income from vermicompost and earthworm production}

Cobb-Douglas production function was used to assess the effect of different explanatory variables on total income from vermicompost and earthworm production. Total income from vermicompost and earthworm production was the dependent variable and the independent variables were volume of earthworm reared, labor use and material cost. Output from production function analysis is presented in Table 4. Material cost was non-significant and negatively associated with the dependant variable. Volume of earthworm reared and labor use appeared to be positively associated with the dependant variable and was significant at $1 \%$ level of significance. This indicated that $1 \%$ increase in volume of earthworm reared keeping other factors constant would increase the income from vermicompost and earthworm production by $0.250 \%$. Similarly, the increase in labor use by $1 \%$, keeping other factors constant would increase the income from vermicompost and earthworm production by $1.015 \%$.

Table 4. Estimated coefficients and their related statistics of production function for the total income from vermicompost and earthworm production in the study area.

\begin{tabular}{llll}
\hline Variables & Coefficients & & $\mathrm{t}$ \\
\hline Volume of earthworm reared $\left(\mathrm{X}_{1}\right)$ & $.250^{* *}$ & $(.077)$ & 3.25 \\
Labor use $\left(\mathrm{X}_{2}\right)$ & $1.015^{* *}$ & $(.299)$ & 3.39 \\
Material cost $\left(\mathrm{X}_{3}\right)$ & -.020 & $(.255)$ & -0.08 \\
Constant & -1.172 & $(.826)$ & -1.42 \\
\hline Summary statistics & & & \\
\hline Number of obs & 32 & \\
$\mathrm{~F}(3,28)$ & $133.61^{* *}$ & \\
Prob $>$ F & 0.000 & \\
R - square & 0.935 & \\
Adjusted R - square & 0.928 & \\
Return to Scale $\left(\sum\right.$ bi $)$ & 1.285 & \\
\hline
\end{tabular}

Source: Field Survey, 2013

** Significant at $1 \%$ level of significance

Figure in parentheses indicates standard error

The F-ratio was highly significant at $1 \%$ level of significance which indicates that the variation of total income from vermicompost and earthworm production mainly depends on the explanatory variables included in the model. The value of $\mathrm{R}^{2}$ and adjusted $\mathrm{R}^{2}$ were 0.935 and 0.928 respectively. Both have similar interpretation. The $\mathrm{R}^{2}$ value indicated that $93.5 \%$ of the variation in dependant variable was explained by independent variables which were included in the model. From the results obtained, it can be concluded that volume of earthworm reared and labor use are the significant factors contributing to income from vermicompost and earthworm production.

The summation of all the regression coefficients of the estimated production function i.e. return to scale was 1.285 which indicates increasing return to scale as the value is greater than one. 
Resource Use Efficiency (RUE) and required adjustment in Marginal Value Product (MVP) of each resource in vermicompost production

The unit of all the variables included in the analysis was rupees. So the marginal fixed cost was one in each case. The efficiency ratio was less than unity for volume of earthworm reared and material cost revealing their over utilization. But the efficiency ratio was greater than unity for labor use indicating it's under utilization. Result showed that none of the variables were utilized to optimum economic advantage. Thus there is need for adjustment in the marginal value product of all the variables to ensure optimal use. The volume of earthworm reared is required to increase by $300 \%$ whereas the labor use is required to increase by $1.48 \%$ only to achieve optimum economic advantage. Material cost is non-significant in production function analysis (Table 5).

Table 5. Estimated Resource Use Efficiency (RUE) and required adjustment in marginal value product (MVP) in percentage for vermicompost production in the study area.

\begin{tabular}{lllll}
\hline Variable inputs & MVP & MFC & r & D \\
\hline Volume of earthworm reared (NRs.) & .250 & 1 & .250 & 300 \\
Labor use (NRs.) & 1.015 & 1 & 1.015 & 1.48 \\
Material cost (NRs.) & -.020 & 1 & -.020 & 4900 \\
\hline
\end{tabular}

Source: Field Survey, 2013

MVP = Marginal Value Product

$\mathrm{MFC}=$ Marginal Factor Cost

$\mathrm{r}=$ Efficiency ratio $(\mathrm{MVP} / \mathrm{MFC})$

$\mathrm{D}=$ Absolute value of percentage change in MVP of each resource

\section{CONCLUSIONS}

Training and extension programs and campaigns should be launched to disseminate the technology to the farmer's level. Farmers' groups should be developed and strengthened. Government should show its concern in order to make people adopt this technology. Appropriate policies regarding technical manpower generation and extension should be formulated in order to create good coordination among producers, traders, consumers and extension organizations.

\section{ACKNOWLEDGEMENTS}

The Authors are thankful to Institute of Agriculture and Animal Science (IAAS) and Department of Agricultural Economics (IAAS). They are also grateful to CQU/IAAS PSLP Biowaste Management Project, Australia/Aus-AID which provided necessary financial support and assistantship for this research. Special thanks should be given to the respondents of the survey for the valuable information, precious time and co-operation during the field visit.

\section{REFERENCES CITED}

Agriculture diary. 2013. Agriculture diary. Government of Nepal, Ministry of Agriculture and Development, Agriculture Information and Communication Center, Hariharbhawan, Lalitpur, Nepal.

Gujarati, D. 1978. Basic econometrics. McGraw Hill Book Company. New York. pp. 98-99.

Hiremath, S. S. 2013. A study on impact of training conducted on vermicompost production technology. International journal of agronomy and plant production 4 (5): 1118-1121. 
ICIMOD. 2011. Vermicomposting Nepal : Gadyaula prayog gari mal banaune pravidi (in Nepali). Godavari, Lalitpur, Nepal.

MoAD. 2013. Agricultural Development Plans. Nepal government, Kathmandu, Nepal.

Practical Action Nepal. 2008. Best practices on solid waste management of Nepalese cities. Practical Action Nepal, PO Box 15135, Pandol Marga, Lazimpat, Kathmandu, Nepal.

Prajneshu, G. 2008. Fitting of Cobb-Douglas production functions: Revisited.agricultural economics research review 21: 289-292.

Rahman, S. A. and A. B. Lawal. 2003. Economic analysis of maize based cropping systems in Giwi local Government area of Kaduna state, Nigeria. An international Journal of Agriculture Science Environment and Technology 3(2): 139-148. 